\title{
SOCIAL WORK PRACTICES IN HUMAN RESOURCE MANAGEMENT
}

Madhukar N. Kulkarni*

Abstract
Social Impact : The social structure in India, under the onslaught of
the globalization is crumbling yielding place to individualism,
materialism and consumerism. The joint family system is almost a
thing of past, replaced by the nuclear family. Growing literacy of
women, women entering into employment market for career and to
support the family in these days of higher cost of living has created
the need for and existence of double income families. Increasing
consumerism has changed the value systems and home/social
environment where, ' I', 'me' and 'myself' is becoming a new personal
agenda and slogan. No one have time for the other. Higher competition
has brought in growing insecurity and fast paced life. Increased working
hours and materialistic life style has spurred emotional disconnect,
bringing to centre stage emotional trauma, despair and helplessness.
Atrocities on women are increasing, women is being comodified, crime
rate is growing and mental health of the society is under severe threat.
The divorce and suicide rates are growing and the society is becoming
internally hollow in the midst of material surplus. India is going from
one extreme of social security under socialistic philosophy to the other
extreme social insecurity under the capitalism oriented globalized
environment.

* "Ameya", 29/2A, II *Phase, Nanjappa Layour, Dodda Bomma Sandra, Vidyaranyapura, Bangalore560097. 


\section{Introduction}

\subsection{Industrial and Commercial Working and Importance and Commercial Working and Importance of HR}

The principles and practices of social work are universal, all pervasive and applicable in every setting wherever there are human beings. The industrial and commercial organisations where human beings work under a framework and for time bound goal, the application of the social work principles and practices is likely to differ from other areas. In the industrial and commercial organisations in the preglobalised protectionistic environment the trigger for employing the social work graduates as welfare officers came from the need for compliance with the provisions of the Factories Act 1948. In the pre globalised protected economy prior to 1990 the HRM, then popularly called as the Personnel Management had more policing and welfare orientation, however in the globalised economy today the HRM function has the performance orientation.

\subsection{Changing Profile of Business}

There is almost a 180 degree change in the way the business was done in the pre-libersalised economy and the way it is done in the post liberalised economy since the 1990s in India. "Globalisation" as a theme has been occupying the centre stage of discussion in many a fora on Economy, Industry, Technology, Marketing and Management in the recent days. The far reaching changes unleashed by the forces of globalisation has tremendously impacted individual, industrial, social, economic, political and national life since the last decade, especially in the past five years. What challenges the forces of globalisation have thrown up cannot properly be grasped, as about their scope as also their intensity unless the conceptual and contextual background of the term globalisation is understood. Let's briefly have a bird's eye view of the conceptual and contextual background.

\subsection{Pre Reform Economy in India}

Capitalism - free trade - laissez faire - individual liberty in trade, and socialism State control on trade industry and Commerce - collective welfare are the two be extremes of politico economic ideologies reigning in the World. The United States of America and England have been the flag bearers of capitalism while the erstwhile USSR, China etc., have been following the socialistic pattern of society. However over the years the economic contradictions built in the socialistic countries based on the Welfare State concept, due to isolation from the world economy, utter lack of competition in the market, created economic crisis and socio political 
disorders, and the communism as a politico economic ideology crumbled resulting in disintegration of the USSR and the falling of the Berlin wall by 1990s. Now changes in the form of common Euro currency emerged with effect from 1.1.1999 in the European block countries with far reaching consequences in the world order. The trade barriers among the countries irrespective of political ideologies broke down. China is a case in point.

India on account of having been under the British empire for over 300 years had suffered heavily, the evils of capitalistic economic policies resulting in the natural resources of India being plundered by British. No industrial development worth the name had taken place in India when India got her Independence. Thus in view of the socio economic realities such as illiteracy, all pervasive poverty, absolute lack of private capital and all round backwardness at the time of freedom of the nation, founding fathers of our country considered it fit and necessary to have a mid off the left economic pattern i.e., mixed economy and declared India a welfare state in its constitution adopted in 1950. Through the concept of welfare state, the government exercised state control in economic policies and gave prominence to the public sector drawing heavily upon the ideologies of socialism. Thus the government controlled economic and industrial life in India through centralised planning and in order to protect the labour which it considered to be the weaker section of society, legislated on almost every area of labour management relations in the light of the Directive Principles of the State Policy enshrined in chapter IV of the Constitution, more specifically articles 41,42 thereof. The protectionistic pattern of economy erected through legal barriers on the Import/export, the Industrial policy stipulating license/quota system to curtail monopoly/oligopoly, the tax structure to sustain the socialistic policies of welfare etc., created through laws like MRTP Act and FERA a situation in India prevailed by late 1980s, that stifled private enterprise. A huge edifice of public sector industries, total lack of competition, high cost Economy through falling productivity, inefficiency and militancy of labour, rising poverty and illiteracy and mounting internal and external debt resulted as a consequence of several other factors like the huge import bills, mainly for the import of the petroleum, oil and lubricants (POL) contributed to the grave economic crisis faced during 1989.

The situation became so grave by 1990 s that India's forex reserves fell and India had to approach IMF for a loan of $\$ 5$ billion which was granted with severe conditions like:

- Introduction of structured adjustment policy leading to LPG (liberalisation, privatisation and globalisation)

- Devaluation of the Indian Rupee

- Reducing the Fiscal deficit 
These imperatives forced India to usher in the economic reforms during 1991. This process has led to the III phase of economic reforms and liberalisation, paving way for government slowly withdrawing from the business and Industry through privatisation and disinvestment of public sector, facilitating the entry of Foreign Direct Investment, and technology, promoting competition by allowing entry of MNCs and TNCs which have brought the latest technology in India.

This process of liberalisations privatisation and globalisation has further been accelerated by the signing of the World Trade Organization Treaty - a successor to the General Agreement on Trade and Tariff. The W.T.O. is a body, which facilitates multilateral trade and commerce in goods and senvices and provides for a level playing ground for the countries across the globe. Today the WTO has over 143 members.

The breakdown of the ideologies of socialism consequently state control, the emergence of WTO, tremendous development in the field of technology, especially the information technology, resulting in ultra fast communication through internet has opened up the market across the globe, and thus what was inconceivable just a few years ago has become a solid reality i.e., furning the world into a global village. The whole world has become a market and manufacturing unit combined, any product may be produced anywhere, even in parts, and can be sold anywhere in the world. Thus business has thus indeed become globalized.

\subsection{Personnel Management in Pre Globalised Economy}

Historical compulsions demanded that India should have a Protected economy to ensure that the indigenous industry and commerce is not destroyed by unhealthy and premature competition from foreigners. This brought in the commanding presence of public sector and monopoly and a stagnant and shortage economy. The unemployment problem, technological backwardness and availability of cheap labour ensured employment of large workforce in the organisations resulting in protected work force by the able support of the government which viewed itself as the protector of labour and enacted several pro labour legislation. This gave rise to the growth of trade unions, emphasis on collectivism, turbulent industrial relations and a focus on labour welfare. Thus the personnel management during this period was more of welfare service providing, legalistic and policing nature. The command and control approach and structure of the organisation laid greater emphasis on discipline and compliance of regulations rather than the performance. Industrial bureaucracy emerged out of this command and control structure. The personnel function involved fin carrying out thus the peripheral functions and was considered as a necessary evil of the management. 


\subsection{Role of Social Work in Personnel Management}

The role social work played in personnel management was very evident in the welfare function in the organisations. By and large the social work trained personnel were employed as welfare officers in compliance with the provisions of the factories Act 1948. The focus was on the welfare management, and to ensure that there is no industrial relations problem upsetting the production schedule. Hardly any effort was involved in the direction of improving the capabilities of the employees except for taking care of the workers education programme under the Central Board of Workers Education scheme. Compliance of the various labour legislation, filing umpteen number of returns under the various labour laws.

\section{Economic Reforms and Globalisation}

In a pre globalised monopolistic business environment there was a constant demand and supply gap with demand always outshipping supply. There was a cost plus profit scenario; ie., the pressure on cost reduction was non existent. The manufacturer could add 20 to $25 \%$ to his manufacturing cost as profit margin and sell his products and services, however now in globalised economy the order is reverse, and the market has become extremely price sensitive.

$$
\begin{aligned}
& \text { Earlier : COST + PROFIT = SELLING PRICE } \\
& \text { Now : SELLING PRICE - COST }=\text { PROFIT }
\end{aligned}
$$

Thus it has become imperative to reduce the cost in every operation because it is the market forces (demand and supply position) that determine the selling price. Customers would prefer least selling price when other parameters are equal. Hence there is only one alternative and that is to reduce cost to the bare minimum constantly. In this drive the contribution of each and every employee becomes imperative.

\subsection{Triggers for Economic Reforms in India}

Apart from the conditions put forth buy the IMF and the World Bank mentioned in point 1.3 there were other pressing internal problems which had generated the internal economic crisis like the high cost economy falling export earnings unable to support the import bills of mainly the $\mathrm{POL}$, utterly non competitive industry producing low quality products unworthy of export market, unmanageable subsidies in almost every sector resulting in unfavourable political fallout acted as triggers to the economic reforms in 1971. India was forced to keep pace with the winds of liberalisation to energise the national economy. For resurgence of 
the economy, infrastructure development was crucial which needed enormous investment. All these pressures created an unprecedented need for liberalisation of the economy.

\subsection{Economic Reforms and LPG}

The economic reforms ushered in lot of far reaching changes in every area of society more in the business and commerce. The economic structure built over the years in the protectionist era involving the legal and economic barriers to free trade was slowly dismantled. The social justice philosophy guiding the industrial policy of the government has yielded place to pragmatism. Industry and commerce is now allowed to function on the terms of global trade practices. The status of commanding heights accorded to the public sector in the earlier era is no longer valid. There is a greater level playing field for the industry and commerce in every sector. Such of the organisations in the public sector who failed to live up to the emerging standards of the global markets were allowed to be disinvested and privatised. The economic structure was liberalised and in the process the industry, including public sector and commerce globalised. Now the local industry is required to compete globally. Those who can compete on the global terms of cost, quality, speed of delivery and innovation only can survive on their own, and others perish.

The pro and anti globalisation forces continue to debate the desirability of globalisation depending upon their own ideological dispositions. But the statistics reveal the story.

The comparative status of Economy (Macro economic parameters.)

\begin{tabular}{|l|c|c|}
\hline & Pre reform (1990) & 2006 \\
\hline Growth rate & $0.8 \%$ & $8.1 \%$ \\
Industrial Growth & $2.0 \%$ & $6.5 \%$ \\
Export growth & $2.0 \%$ & $10 \%$ \\
Inflation rate & $14.0 \%$ & $5.40 \%$ \\
& & projected $4.50 \% *$ \\
Forex & $\$ 1$ Billion & $\$ 140$ Billions \\
\hline
\end{tabular}

*For 2006 as on 28.2 .2006

In addition to the above figures giving comparison of the position of the economy immediately before economic liberalisation with the post liberalisation era, some other indicators like as regards the explosion in the communication facilities like 
the telephones and the internet which have have tremendously impacted the business are noted below:

\section{Growth of Telephones}

Fixed Lines

\begin{tabular}{|c|c|c|c|}
\hline Year & PSUs & Private & Total \\
\hline $2001-02$ & 37.90 & 0.52 & 38.42 \\
$2002-03$ & 40.53 & 1.10 & 41.63 \\
$2003-04$ & 40.49 & 2.36 & 42.85 \\
$2004-05$ & 41.11 & 5.09 & 46.20 \\
$2005-06$ & 40.70 & 7.01 & 47.71 \\
\hline
\end{tabular}

Mobile

\begin{tabular}{|c|c|c|c|}
\hline Year & PSUs & Private & Total \\
\hline $2001-02$ & 0.26 & 6.28 & 6.54 \\
$2002-03$ & 02.64 & 10.35 & 12.99 \\
$2003-04$ & 05.99 & 27.70 & 33.69 \\
$2004-05$ & 10.97 & 41.20 & 52.17 \\
$2005-06^{*}$ & 16.48 & 61.60 & 78.08 \\
\hline
\end{tabular}

*Apr- Dec

Millions

One of the indications of the health of the economy is the containment of the inflation rate which has come down drastically over the year and now hovers at around $5 \%$ as can be seen from the table below:

Annual Point To Point WPI Inflation

\begin{tabular}{|c|c|c|c|c|}
\hline Year & $\begin{array}{c}\text { Primary } \\
\text { Articles }\end{array}$ & $\begin{array}{c}\text { Fuel, Power \& } \\
\text { Lubricants }\end{array}$ & $\begin{array}{c}\text { Manufac- } \\
\text { tured Goods }\end{array}$ & All ltems \\
\hline $2001-02$ & 3.90 & 03.90 & 0.00 & 1.60 \\
$2002-03$ & 6.10 & 10.80 & 5.10 & 6.50 \\
$2003-04$ & 1.60 & 02.50 & 6.70 & 4.60 \\
$2004-05$ & 1.30 & 10.50 & 4.60 & 5.10 \\
$2005-06^{*}$ & 5.70 & 07.90 & 2.80 & 4.50 \\
$2004-05^{*}$ & 1.00 & 10.20 & 5.40 & 5.40 \\
\hline
\end{tabular}

*as on $22 \operatorname{Jan} 2005$

In Millions 
Similarly the number of man days lost due to strikes also is a good indication of the spurt in the industrial and commercial activity. The following figures show a drastic reduction in the mandays lost due to labour problems.

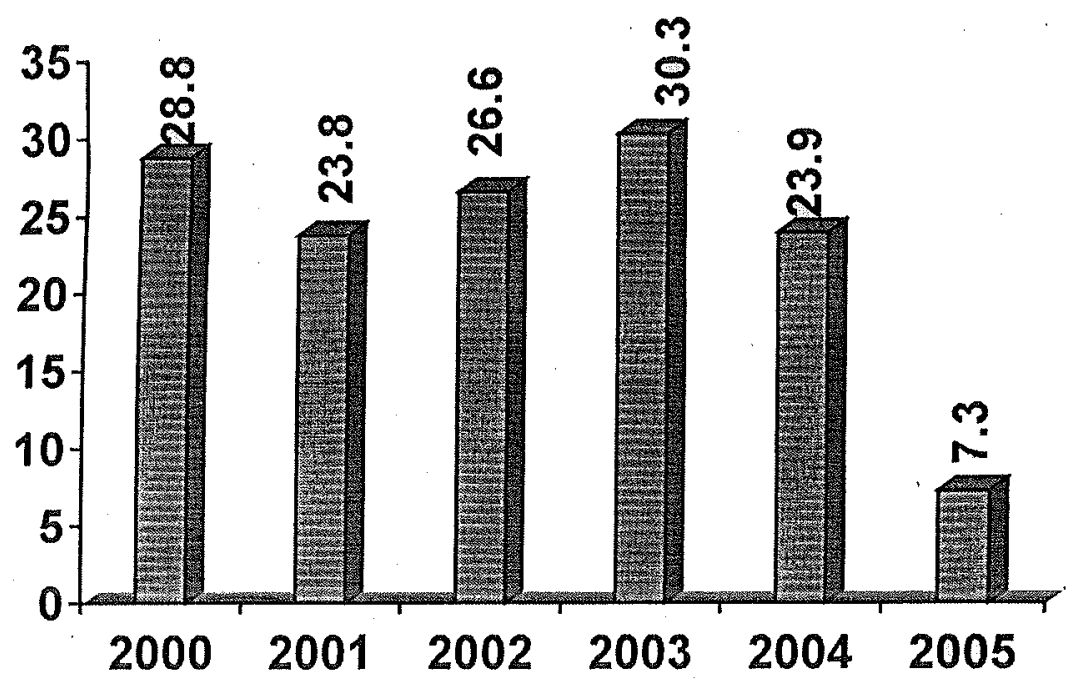

⿴囗大 Mandays Lost in Mn

The crux of the term "Globalisation" essentially is the closer integration of any country's economy and therefore its market for goods and services as well as financial assets with the International economy. Sri Lanka was one of the foremost countries to globalise its economy as early as in 1970s.

\subsection{India - A Hub of Manufacturing}

In the past decade India has emerged as leader in software exporting billions of dollars worth knowledge products. There is a mushrooming growth of the service sector, especially the Call Centres, and other BPOs contributing considerably more and more over the years to the GDP. The bio technology sector also is emerging in a big way in India. However the biggest development is that the manufacturing sector has put India on the world map as the manufacturing hub of the world, as can be seen by the fact that India has emerged as most sophisticated supplier of the auto part to the major auto giants like the General 
Motor and Ford Motors who have set up their manufacturing plants in India to garner the benefits of the intellectual power of the knowledge workers and cheap labour of India. This has brought in the most advanced and sophisticated technology to India. India is truly on the road to becoming a super power.

\subsection{Impact of LPG on HRM}

The HR function has become central to the business in view of unprecedented changes in technology and competitive environment

a) Growing importance of service function and increasing role played by female workforce.

b) Continuous upgradation of talent so that employees remain employable

c) Talented employees need an enabling and motivating environment for professional excellence.

d) The compensation packages have to be attractive to attract and retain best talent.

e) There is a greater emphasis on team performance along with individual professional excellence which calls for flatter organisaional structures unlike in the past.

f) Multi skilling and multi dimensional professional knowledge orientation of employees have become imperative for employment.

g) Outsourcing of peripheral functions including in production operations has become the order of the day.

h) Just in time philosophy requiring enormous co-ordination has become a must.

i) Management and matching of competency level of employees to the changing requirements of the organisation has become crucial. It is the quality of $H R$ available in the organisation that ultimately makes the difference in performance and profits.

i). Performance management through improved systems of performance assessment of employees.

k) Ensuring satisfaction of internal customers for maximum satisfaction as external customers satisfaction.

1) Cultural implications have growing impact on the business.

m) Breakdown of paternalistic, welfare oriented approach and emergence of performance oriented approach in management. 
The above is only an illustrative and not an exhaustive list of challenges before HRM thrown up by the process of globalisation.

\subsection{Drivers of Business:}

In the globalised economy in the new millennium the products and services need to be of world class quality and hence to get such quality output from the employees the HR professionals must also meet high standards. In the globalised economy the organisation must focus on:

- Speed of Delivery

- Quality

- Cost

- Innovations

- Customers' Satisfaction

\section{Market Economy and Challenges to H R M}

\subsection{Breakdown of Old Order}

The economic reforms dismantled the old protectionist structure built over forty years, and government slowly started adopting the role of facilitator to the business. The dismantling of the old structure is elaborately described above. The industry and commerce which was monopolistic hence lethargic over several decades suddenly went into overdrive after the economic reforms, which tremendously impacted the HRM function as suddenly there was emphasis on the efficiency in every area of working. Simultaneously the development in information technology and the communication technology tremendously influenced every conceivable area of working bringing in speed and flexibility in working. The human spirit of entrepreneurship and achievement was unleashed in this new environment and competence became a watch word at every strata of working paving way to paradigm shift in the human resource management. Personnel management became human resources management. Knowledge workers emerged in this process, individualism, flexy working time reduced the importance of the Unions in the organisation. Return on investment became the crucial consideration in everything. Because of continual changes human resource development assumed incredible importance. Human Resources Management, perhaps is single function which has seen the maximum changes. 


\subsection{HRM Myths shattered}

The globalised economy has shattered many myths of the past.

Myth I: That the skilled labour is abundant and easily replaceable. Contrary to this assumption that India being a populous country having world's third largest technical manpower, skill is no problem, but the reality is there is a severe dearth of required skill sets which keep on changing.

Myth II: Managing Human Resources is a staff function is another myth that is shattered. Human Resource function is not a staff function but it is a line function and the HR Manager is only a facilitator and expert advisor.

Myth III: That labour lack mobility. In the globalised economy the fourth generation labour is more mobile than ever. Indeed Indian labour and executives have made greater mark outside India than within.

Myth N: Experience is important in working life. It is no longer so, in a fact changing work environment the knowledge and skill requirement, also ever changing on account of newer technology replacing the old at a faster rate has shifted the emphasis from experience to learn ability. The ability to learn faster has become more important than experience.

Myth V: Specialisation is the key to success: This is only half true. Indeed it is imperative to give expertise in one's own area but one cannot be, isolated from other areas. One must also gain knowledge of other functions and skills. Today a welder also must know about machining, drilling operation and be able to operate CNC machines. The HR Manager must know about finance, production and other functional areas.

\subsection{Socio-psychological Implications of Globalisation}

Implications of globalisation are enormous from the social work perspective and throw up multifarious challenges to deal with:

* The breakdown of lifetime employment creates a constant state of uncertainty and job insecurity creating havoc on emotional health of employees.

* Constant demands on professional competencies mean tension of continuous upgradation of skill and knowledge.

* Consumerism and rising costs drive the women folk also to engage in employment creating tension in family. 
* Breakdown of joint families leading to insecurity in old age and lack of emotional support of older generation to the growing children, due to forced emergence of nuclear families.

* Fierce competition brings increasing insecurity of employment and spells of unemployment due to market forces in terms of retrenchments and layoff.

* Tension ridden life may drive employees to seek solace in drugs and alcoholism endangering families.

* Rising consumerism is likely to sap family savings endangering safely in families and drive them into indebtedness spelling a cycle of doom.

* High pressured working life of tension is leading to insomnia, depression and psychosomatic disorders.

* The inexorable forces of change may lead to stress and related debilitating diseases like hypertension, diabetes.

* Increasing age of marriages due to socioeconomic reasons likely to cause social debasement due to prostitution, sexual exploitation of single women and violence in family.

* Cultural debasement as seen growing in recent years, corrupting the youth.

* Growing suicidal tendencies due to frustration and inability to cope with the stress and tensions

\subsection{Role of HRM in the Organisation in the Globalised Economy}

In the new millennium the HR professional must think in terms of the roles he has to perform rather than the jobs he has to do. Performance of the job is a bygone concept and now one must think in terms of the performance of one's role which is a much wider concept. Keeping in view the following bullet points pertaining to the HRM function in the organisations the HRM professional from social work discipline must remodel his role in the organisation.

- $\quad H R$ is now central to business

- Most routine HR functions are outsourced.

- HR is now to focus on the core business needs.

- HRM is now a multi-disciplinary function. 
- Core knowledge of customers and business needs is the essence of HRM to build required competition.

- Use of technology in HRM functions - e_hr.

- Agility and pro-activity with other functional heads is a must - No compartmentalized working.

i. Change Agent's Role:_must be constantly sharpening his competencies to act as an agent since change is the only constant factor. Change must never be fought but must be embraced. HR manager must prepare the mindset of the employees for change.

ii. Facilitator's Role: HR professional has to be a facilitator to help employees to build up their competencies according to the organisational requirement. The command and control economy was stagnant hence controlling the external behaviour was a challenge and needed a policeman's role. Now it is the management of diversity and learning ability, on the part of all, is the most important thing which requires facilitation.

iii. Friend and Guide's Role: In the tension ridden employment HR professional has to be a friend, guide and philosopher to employees on every sort of problem whether personal or occupational. There comes a need for all at one time or the other for a true friend who can give right advice, HR manager should fit that role.

iv. Team Player's Role: HR professional has to be a team player along with other functional professional shunning the traps of commander and controller to help perform their role effectively. This perhaps is one of the most important roles because in command and control economy hierarchy is important but in a fast changing organisation it is your team work that gives the most appropriate response. In team players individual expertise and self management is extremely crucial.

v. Businessman's Role: The success of an organisation depends upon the wealth it generates through effectively satisfying the customers. HR professional has to understand the dynamics of business, and requirements of cost control. The dynamics of business today directly affect the HR function and vice versa. Unless HR manager is speaking the language of NPAs and $\mathrm{ROI}$ he will be not be taken seriously.

vi. Active Listener's Role: HR professional may not be able to solve all the problem of employees but at least he can be an empathetic and active listener. Many problems get dissolved if they are actively listened to. Active listening is extremely important and is one of the most difficult of the skills to master. 
Counselor's Role: The pressures of working today are such that almost everybody requires personalised attention and counseling either for performance improvement and adjustment or for coping up with consequent emotional problems including srtess. The HR manager must equip himself / herself for this role. This role require lot of empathy and patience and non judgmental attitude.

\subsection{HRM Competencies Required in Globalised Market}

The competencies the HR professional will be called upon to exhibit in the new millennium are:
a) Team building Competency
b) Leadership Competency
c) Diversity Management Competency
d) Negotiation Competency
e) Change Management Competency
f) Cost Reduction Competency
g) Performance / Potential Assessment Competency

\section{Social Work Perspective and HRM}

\subsection{Globalised Market Environment and Psychosomatic Disorders}

The social structure in India, under the onslaught of the globalisation is crumbling yielding place to individualism, materialism and consumerism. The joint family system. is almost a thing of past, replaced by the nuclear family. Growing literacy of women, women entering into employment market for career and to support the family in these days of higher cost of living has created the need for and existence of double income families. Increasing consumerism has changed the value systems and home/social environment where, ' $l$ ', 'me' and 'myself is becoming a new personal agenda and slogan. No one seems to have time for the other. Higher competition has brought in growing insecurity and fast paced life. Increased working hours and materialistic life style has spurred emotional disconnect, bringing to centre stage emotional trauma, despair and helplessness. Atrocities on women are increasing, women is being comodified, crime rate is growing and mental health of the society is under severe threat. The divorce and suicide rates are growing and the society is becoming internally hollow in the 
midst of material surplus. India is going from one extreme of social security under socialistic philosophy to the other extreme of social insecurity under the capitalism oriented globalised environment.

\subsection{Business Dynamism and Multiskilling of Social Worker / HRM Professionals}

The social work trained HRM professionals need to realise that on account of the fierce competition and cost considerations the employers resort to loading all kinds of responsibilities, this is especially so in the smaller organisations. Therefore it is imperative that the HRM professional equips himself with as many capabilities as possible. This includes administration, co-ordination, public relation and liaison work, besides his domain knowledge and competencies. He must possess sufficient knowledge of the core business processes and dynamics, some knowledge of the marketing and customers, and some knowledge of the finance of the organisation. The knowledge and competence in the usage and handling of the computers and information management is absolutely a must.

\subsection{Need for Social Work Trained HRM Professionals}

The need for social work in the society has always been there. The growth of industrialisation brought around class structure in sharp focus and social work as a profession emerged from the shadows of clarity and philanthropy. 'Helping the person to help himself' is the cornerstone of social work principle and philosophy. That in the bygone days related to helping an unprivileged person to acquire the material resources to survive and grow as the demands on one's emotional and intellectual self were not much to speak about. Social work as a profession found its application much to fight the social evils of inequality squalor poverty and illiteracy and on emotional side in the abnormal psychology as psychiatric social work to deal with mental ill health. It did not touch up on the normal capable human being as a target group, requiring the services of social work profession. Social workers as professional were much in demand for community organisations where victims of society need help from social workers, whether the destitute woman or street children or the aged or diseased. Normal capable human beings in productive calling did not have the need for social worker as a professional.

Social worker professional with a systematized body of knowledge in sociology psychology, economics, law and a host of other social sciences, and with case work and group work as tools and techniques, forming the methodology of social work is a veritable friend, guide and philosopher of the society. Though in Industrial organisations his services were sought as welfare officers, who eventually. graduated as personnel managers in the old economy, the ground realities in 
the field restricted use of his social work knowledge and philosophy and required him to become more of an administrator and legalistic manager, killing the basic philosophy of social work. The spirit of social work of creating capability in people to sustain themselves, got killed in the deluge of legislations and conflicts, he was required to manage in the organisations which is not so now in the globalised market oriented organisations since building and developing the capabilities of the employees is the focal point of the role of the HRM professionals.

\subsection{HRM and Social Work Education}

The profession of HRM which earlier a preserve of social work trained professional armed with a legal degree, has over the years become generic as the legal and Industrial relations orientation in the man management has been replaced by the business, behavioural and technological orientation, now the HRM profession has been invaded by professionals from other disciplines like information technology, Engineering, Finance, Industrial engineers, even secretarial practice. For sometime now there has been an impression gaining ground that HR job can be done by almost anybody! Therefore the competition and challenge for the social workers hoping to become the HR professionals is not only acute but all around. Therefore the social work curriculum has to keep pace with demands of the business. Greater emphasis on the business dynamics in the social work curriculum for the HRM specialisation is a must.

\subsection{Need for reorientation of the Social Work Education:}

By and large the inputs given to the students are generic. It is like wearing the same cap for all the occasions! The needs of HRM are today specific and more business oriented. Therefore the course content needs to be more appropriately drawn possibly in consultation with the industry managers.

\section{A. From the point of view of the Social Work Educators:}

a) Industry Experience: Those who teach the HRM subjects in the Institution should have at least of some years practical industry experience.

b) Membership of Professional Bodies: The Social work educators as Institutions and individual educators are suggested to become members of professional bodies like the National Institute of Personnel Management and The National HRD Network, The Karnataka Association of Professional Trained Social Workers etc. to keep abreast of the developments in the professional area and bring the up-to-date knowledge to the students.

c) Greater co-ordinations with the Industry: Greater co-ordinations with the industry is required on the part of the guides who guide the students in 
the field work and the project work. It was experienced that the students are made to fend for themselves in the name of self help, which badly affects their performance in field work agency, and reputation interfering with the chances of their absorption after the course completion.

d) The industrial tours need better focus: The industrial tours need not degenerate to sight seeing tours as often they do. It has been personally experienced the students give more importance in drawing up the tour agenda to sight seeing more than the visit to the industry. Specific programme and agenda need to be drawn upon for the practical inputs form the industry visits and assessment of knowledge gained.

e) Personality and communication skill development: Greater efforts must be made towards the personality and communication skill development of the students as it is found that the students taking up social work course are mostly drawn from rural areas and need specific inputs to gain confidence to face the industrial environment.

\section{B. The Point of View of the Social Work Students:}

Knowledge of business dynamics: Because of better equipment in knowledge and business requirements MBAs are getting more preference in HRM. This is so perhaps because the course direction and content is more business oriented in case of the MBAs than the Social work professionals whose course direction and the content is designed more for the pure social work than the business and the $H R$ is one more appendage.

a) Communication Skills: The most vital aspect of success in any field and more so in the business is the cultivation of the attractive written and spoken communication skills. By and large communication skills for social workers need to be improved.

b) Mismatch in ambition and preparation: Though the ambition of Social work professionals opting for HRM is to become HRM Professional, yet their turnout, outlook and approach is like social worker and not a business manager which is a mis-match. They need to talk the lingo of business.

c) Wider reading is a must: Though this weakness can be said to be the common weakness, the social work professional must display greater desire orientation, hard work and preparedness in equipping themselves with the domain knowledge and general business related knowledge, like the micro. and macro economic issues, psychology the political environment. 
d) Membership of Professional Bodies: The students are suggested to become members of professional bodies like the National Institute of Personnel Management and The National HRD Network, The Karnataka Association of Professional Trained Social Workers etc. to keep abreast of the developments in the professional area.

\section{Conclusion}

It is said that "Business is like oil it does not mix anything except oil." Even if social work profession is value based and its goal is to create a human society devoid of wants and fully capable human beings it won't appeal to business / industry as their immediate and continuing need is profit maximization and growth through the HRM. Therefore the HRM professionals must speak the language of the businessmen. Only those who understands this fundamental business need and adopt the necessary practices can succeed.

The HRM professionals armed with a degree in social work have their jobs cut out in these fast-changing times. The HR professionals must capitalise on the merits of glóbalisation and beware of its demerits. The HR professionals must get to know the cost factors and the business dynamics and processes of the organisation they are working for. Hence HRM Social Work Education and practices need to be reoriented to the Industry needs to find greater acceptance.

\section{References}

1. The Constitution of India by Anand

2. Personnel Today issues published by the NIPM

3. Business Today issues

3. Economic Times Budget issue dated 28.2.2006

4. Business India issue. 